\title{
Research Trends in Technologies Applied to Learning Environments:
}

\author{
Marisol Esperanza Cipagauta Moyano ${ }^{1}$, Adriana Castro Camelo ${ }^{2}$, Francisco Conejo Carrasco ${ }^{3}$ \\ and Adriana Quimbayo Feria ${ }^{4}$ \\ ${ }^{1}$ Corporación Universitaria Minuto de Dios-UNIMINUTO, Colombia \\ ${ }^{2}$ Corporación Universitaria Minuto de Dios-UNIMINUTO, Colombia \\ ${ }^{3}$ Corporación Universitaria Minuto de Dios-UNIMINUTO, Colombia \\ ${ }^{4}$ Corporación Universitaria Minuto de Dios-UNIMINUTO, Colombia
}

\begin{abstract}
Master in Education in virtual modality, offered by Corporación Universitaria Minuto de DiosUNIMINUTO, has the Technologies for Learning Environments among its research lines, in which students develop projects where the main objective is to show the appropriation of technologies within the environments where research is developed. The approach to an issue such as technology in education coincides with the current dynamics that occur in this field, especially since its use in teaching and learning environments has increased due to the incorporation of technological devices into the students' daily lives. Therefore, the school assumes the challenge of appropriating this technology at the service of educational processes, and to address a research project in which technology is the protagonist, demands from teachers, students, and the educational community in general, the willingness to change old practices for new and disruptive ones, changing the perception of technology to make it an ally of the teaching and learning process. For this proposal, the degree projects presented in 2019, registered under the aforementioned research line, were reviewed, making an analysis of the way in which the use of technology impacts on the improvement of the educational quality and the teaching-learning process.
\end{abstract}

Keywords: Education, Quality, Teaching, Educational Contexts. 


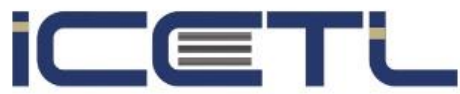

21-23 FEBRUARY, 2020

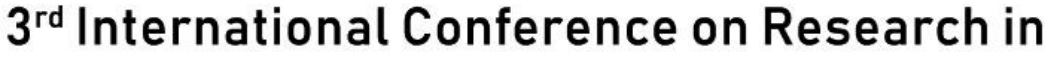 EDUCATION, TEACHING and LEARNING}

ROME, ITALY

\section{Introduction}

The incursion of technology in education is a fact in this era, the digital one. Technology has been present in the academic institutions almost since its inceptions; nevertheless, the introduction of technological tools in a more constant and homogeneous way took place until the 90's and the beginning of the 21st century at all educational levels: elementary, secondary and higher education where technology is applied, used and appropriated. It is evident that the teaching, learning and evaluation process is more dynamic taking into account that there is a great increase in the willingness of students and professors to innovate, create and be disruptive in the way they learn, teach and evaluate. "As the teaching professions face the demands of the digital age, educators require an increasingly broad set of digital skills and strategies" (Redecker, 2017, p. 1).

In agreement with Redecker, it is relevant to clarify that during the last years, the discussion about the role that technology plays in the teaching and learning processes highlights different aspects such as the interaction between the teacher and the student, the implication of the new didactic models, current trends around this educational phenomenon or its impact on the education field through the appropriate use of Information and Communication Technologies.

According to the previous statement, it is necessary to highlight the importance of analyzing the research carried out around didactics and methodologies in which Information and Communication Technologies have an important role in the teaching and learning process taking into account the vision of current education, the emergence of technological developments and contemporary models adopted in this process.

This is why the analyzed works that are part of the research line entitled "The use of technology in learning environments" of the Master's Degree in Education at Corporación Unversitaria Minuto de Dios UNIMINUTO, deal with different topics in which the step by step of the proposed projects are depicted through quantitative and qualitative methodologies. It is important to clarify that the student carries out an applied research over a year and a half accompanied by an assigned tutor who guides the research process and advises him permanently at each stage of the project; at the end of the research, the process concludes with the publication of an article in an indexed journal that is the product of the work done.

In this article, the authors analyze the master's degree projects during 2017 to 2019; for this purpose, a matrix was developed with data such as: thematic addressed, social actors, objectives, support theories, methodology, results, conclusions and the impact generated. Each work was reviewed in detail in order to extract the data that was taken as input to describe the results obtained and identify the research trends in the area of technology applied to education.

The topics addressed by the students in each of their research papers are related to: learning styles in virtual environments; learning styles in collaborative environments; the tutor's influence in the online learning; the development of digital skills; reading comprehension; selfregulation and self-efficacy of learning; the use of the blog for learning foreign languages; use of platforms for learning biology; the personal learning environment and its relation to academic achievement; use of web pages for health prevention campaigns; use of virtual 


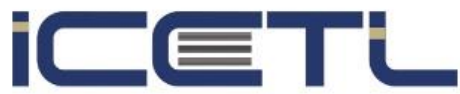

21-23 FEBRUARY, 2020

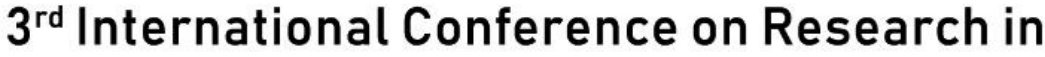 EDUCATION, TEACHING and LEARNING}

ROME, ITALY

learning objects in mathematics; the video game as a didactic strategy; interaction in the classroom, use of "popular songs" in learning English; evaluation of continuous online training in hospitals; use of the blog for reading comprehension; design of teaching units to strengthen the reading act; perception of training methodologies in clinics; emotions and learning; the use of the blog in chemistry learning; digital skills of preschool teachers; use of the blog in learning English; virtual environments and the development of social skills; motivation in the learning of mathematics and the use of technological tools by teachers.

It is necessary to take into account that these themes are directly related to the working and immediate environments of the students and are carried out in order to understand in depth the technological influence on the intellectual commitment that the digital era offers.

Similarly, below are the objectives developed in accordance with the themes addressed and with the contexts determined under the permanent advice of a teacher assigned to the direction of the master's degree in education.

Establish the relationship between learning styles according to Kolb's theory ${ }^{1}$ and collaborative learning in virtual learning environments.

Identify the characteristics presented by high school students between 9 and 12 years, according to their learning styles based on the Honey-Alonso questionary in collaborative learning environments.

Identify the profile of competencies required by higher education tutors to carry out their teaching practice in virtual learning environments and how this act influences the academic performance of students.

Analyse the impact that the integration of the Information and Communication Technologies has had in the classroom, in order to promote the integral formation and the development of digital competences of ninth grade the students at Institución Educativa Distrital Unión Europea.

Evaluate the implementation of the PLEMA ${ }^{2}$ method to verify the impact on the reading and writing comprehension in the first semester students of the technological careers at Corporación Uniersitaria Minuto de Dios - UNIMINUTO.

Unveil the training needs in the use of the virtual platform of undergraduate students at Corporación Uniersitaria Minuto de Dios - UNIMINUTO, Neiva branch, to strengthen selfregulation and self-efficacy in learning.

Describe the incidence of a blog based on collaborative learning in writing descriptive paragraphs in German as a foreign language in students of level A1 at Universidad del Norte.

\footnotetext{
${ }^{1}$ Kolb theory states that learning involves the acquisition of abstract concepts that can be applied flexibly in a range of situations (Awla, 2014).

${ }^{2}$ This method means Pre-reading, Reading, Making, Memorization and Self-evaluation in its abreviations in Spanish.
} 


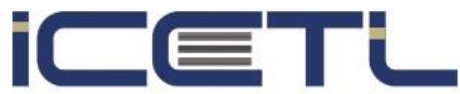

21-23 FEBRUARY, 2020 $3^{\text {rd }}$ International Conference on Research in EDUCATION, TEACHING and LEARNING

ROME, ITALY

Identify the impact of the Edmodo environment on the learning performance of the inheritance mechanisms of Mendelian genetics, in eighth grade students at Institución Educativa Rural Departamental San Antonio.

Assess the impact of a personal learning environment (PLE) on the academic achievement of ball dribling and the launch in the sport of basketball, in sixth grade students at Institución Educativa Agustín Nieto Caballero.

Describe the impact of the campaing "Zero tolerance to Bullying " with the support of the Web page notoleroelacosoesc.wixsite.com/misitio, in the understandings that eighth grade students have about bullying at Gimnasio San Angelo.

Identify the incidence of an OVA based on the game as a pedagogical strategy in the development of the academic achievement of relational logic in the process of division in fourth grade students at Colegio Distrital Paulo Freire.

Analyze the use of the "Direnc" videogame as a didactic strategy for strengthening significant learning skills in the use of the color code of low power resistors in apprentices at SENA Electronic Equipment Maintenance Course.

Establish the incidence of the students' attitudes about the performance obtained in the entrepreneurship module of the Children's Pedagogy Bachelor's Degree when they interact through virtual classrooms at Corporación Universitaria Uniminuto Regional - Neiva.

Learn about the influence of "popular songs" (pop songs) in improving the understanding of English as a foreign language when workshops with activities supported by audiovisual resources are held for seventh grade students at Centro Educativo Rural Tres Bocas in Tibú municipality.

Analyze the impact on health care quality indicators specific to the area of critical care provided by the intensive care nursing staff of a fourth level medical institution that has received continuous training in a semipresential diploma course supported by a virtual learning platform.

Determine the impact on reading and writing skills at the inferential level of the English language when students at "EPFAC ${ }^{3}$ face-to-face Lieutenant and Captain promotion courses" interact with the WordItOut ${ }^{4}$ teaching strategy through study guides mediated by the Blogs tool on the BlackBoard LMS platform.

Determine the curricular elements that the teacher should take into account to design learning units, which contribute to the educational development of the subjects related to the area "Act Reader" offered by the virtual program Information Science and Documentation, Library and Archives at Universidad del Quindío.

\footnotetext{
${ }^{3}$ EPFAC means Colombian Air Force Post graduate School in its abreviations in Spanish.

${ }^{4}$ WorlItOut is a program when it can be found Puffy groups of words that illustrate articles, especially those that are read on the internet.
} 


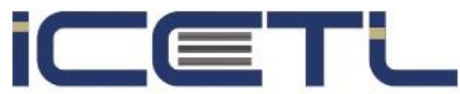

21-23 FEBRUARY, 2020

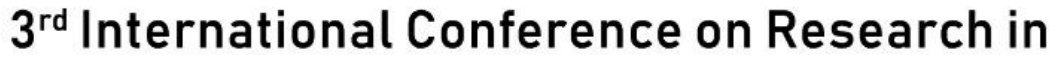
EDUCATION, TEACHING and LEARNING

ROME, ITALY

Establish the perception of the ICU and CCU nurses at Clínica Medellín on the use of the virtual platform (Intranet-Climed) as a training tool on clinical issues.

Analyze the influence of the educational blog as a didactic strategy in the motivation of learning chemistry in tenth grade students at Institución Educativa Libre de Circasia.

Analyze the incidence of the use of the blog as a teaching strategy in the development of oral English skills in tenth grade students at IED Arborizadora Alta.

Analyze the impact of "Edmodo" virtual environment on the development of social skills in 9th grade students at IED Villemar El Carmen.

Identify didactic strategies in mathematics that tend towards significant learning through the use of ICTs in eighth grade students at Henry Daniels Educational Institution.

Analyze the incidence of the tachers' holistic skills to implement "JClic"5 as a technological tool in the Upper Normal School of Manatí at Atlantic department of Colombia.

The diversity of these topics shows how technology is generating changes in education, as stated in a study carried out by Fundación Telefónica in 2018: "the new digital learning technologies are also transforming the education of adults, with new possibilities for them to be trained anywhere and at any time, following more personalized learning itineraries that correspond to their lifestyle".

\section{Methodology}

The impact that technological development has had in different spaces is recognized, with education being one of those that has been affected, which leads to wondering about how the use of technology affects the quality of education and the teaching-learning process of students, in particular, the results, the influence on individual and group performance and resignification in the use of technology for entertainment and for learning. In the same way, the work allows us to recognize the impact in pedagogical campaigns such as prevention of bullying, in the development of skills and abilities in students of different levels of training and disciplines evidenced in their work performance.

For this purpose - as mentioned above - the authors analyzed the degree works researched by the students of the Master's Program in Education at UNIMINUTO Virtual and Distance (UVD) developed during the years 2017 to 2019 from the research project entitled: Use of the ICT in Learning Environments, taken from the UVD "Thesis Deposit".

Through the use of hermeneutical methodologies, 25 degree works researched by the students of the program were analyzed, using the Excel Software, to be able to categorize them and make simple counts of the results. These categories were defined from the existing literature in the

\footnotetext{
${ }^{5}$ JClic is a set of computer applications that are used for carrying out different types of educational activities: puzzles, associations, text exercises, crosswords among others.
} 


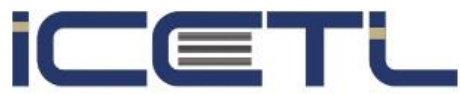

21-23 FEBRUARY, 2020

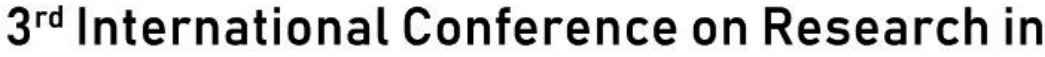 EDUCATION, TEACHING and LEARNING}

ROME, ITALY

field of knowledge, this method is used in various bibliometric analyzes reported in international literature (Fong, Flores and Cardoza, 2017).

The work consisted on three phases, the first one is the description of the research projects and their results, where elements such as: the topics addressed, the social actors, the purposes, the research objective, the supporting theories, the methodologies are addressed, the results, conclusions and impacts generated, in order to establish the current status of the research project. This first phase allows to determine the fields of knowledge addressed, the main users, the intentionality of the research interests, the proposed and pending goals, the literature on which the academic discussion is based, the methods and designs mainly used, the scope and results obtained, evidencing gaps and new requirements for future research. The objective of defining these characteristics is to standardize the criteria of analysis established by the academic program.

The information is recorded in different categories such as: "thematic" which was taken from the project title; "Social actors" that were the subjects and educational institutions that participated in the projects; "Purposes" that are the specific objectives of the investigation; "Supporting theories" that was constructed from the theoretical references selected by the authors mentioned in the development of each research work; "Methodologies" that were recorded according to the guidelines of the methodology chapter; "Results" that were taken from the findings described in the analysis of the results of the research chapter; and, finally, "conclusions" and the "impacts generated" were taken from the conclusions and recommendations chapter.

The fieldwork consisted of a systematic review of the 25 papers, with the joint reading of each thesis emphasizing the general objectives of the works, their conclusions and results. Among the experiences, it is found cases of learning in spaces such as hospitals, in elementary and secondary education, in institutions such as the police, with diverse populations such as: young people of primary and secondary, university students of different semesters, university tutors, and population in technical level assistance in the area of health.

The second phase was the analysis of the documents, taking as a unit of analysis the degree works approved by the different statutes determined by the Master in Education program and which have been reviewed and evaluated by jurors, thus allowing the data to be taken directly from each project. Each paper was reviewed in detail in order to extract the data to describe the results obtained and identify the research trends in the area of technology applied to education emphasizing the impact of technology on the quality of students' teaching and learning processes

The third phase was the systematization of results, which allow to evidence the importance of the teacher's role, the handling of the ICT and the student's motivation so that the process goes beyond the use of the tools and achieves the objective of learning through a committed exercise of the different actors, besides recognizing that although the virtual studies require of autonomous work on the part of the students they handle exercises of orientation and practices that allow that the knowledge is constructed, through the collaborative work, the academic 


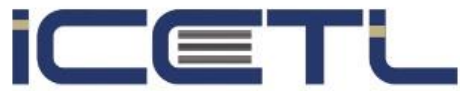

21-23 FEBRUARY, 2020

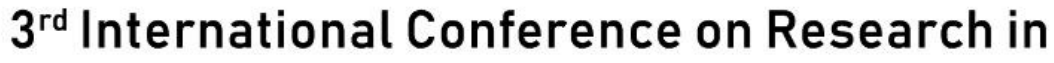
EDUCATION, TEACHING and LEARNING

ROME, ITALY

discussion and the mediation. Needless to say that the comparison is also made between learning with the use and non-use of technology to see the differences, as well as the lag of groups that do not use technology.

It is expected that these results will provide the basis for future researchers to continue building a body of knowledge in relation to the subject studied and documenting the implementation of these practices.

\section{Results}

Regarding the results, the recognition of some transversal axes in the collected research can be highlighted around the different topics on ICT in learning environments:

Table 1: Transversal research themes

\begin{tabular}{|l|l|}
\hline \multicolumn{1}{|c|}{ Thematic } & No. \\
\hline Learning styles and ICT & 4 \\
\hline Teacher competencies & 3 \\
\hline Needs and attitudes of students with ICT & 4 \\
\hline Integral Training and ICT & 2 \\
\hline ICT methodologies, platforms and resources & 9 \\
\hline Collaborative Learning and ICT & 2 \\
\hline Gamification & 1 \\
\hline
\end{tabular}

Source: Database of the research line. Master in Education UNIMINUTO.

It is worth highlighting the great direction of the student-researchers in analyzing the effects and developments of both digital methodologies, platforms and ICT resources as referents of their proposed general objectives. Another significant number also seeks to relate learning styles with proposals in ICT methodology within the classrooms. Needless to mention the tendency to recognize teachers' competencies and knowledge regarding the use of ICT, as well as to establish descriptive studies on the needs and attitudes that students have regarding new technologies in learning environments. 


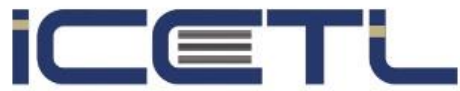

21-23 FEBRUARY, 2020

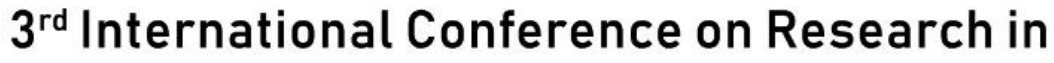
EDUCATION, TEACHING and LEARNING

ROME, ITALY

Finally, this description shows trends in aspects such as gamification and the insertion of video games as didactic proposals in areas of knowledge and the importance of collaborative learning mediated in virtual environments.

In this sense, there are other aspects to take into account in the 25 researches analyzed, such as the theoretical support in the support of each researches. From classical theories in the approach to learning styles or constructivist bases in the development of proposals, to the latest novelties such as the PLEMA methodology as implementation axes in some studies.

A large part of the research was done using a qualitative and mixed methodology, as opposed to pure quantitative methodology. This occurs because within the themes, descriptive elements, attitudes, perceptions, etc. of the different objects of study are addressed and because the researcher seeks a depth of data that allows him to identify the phenomena addressed.

Figure 1: Applied Methodologies on Researches

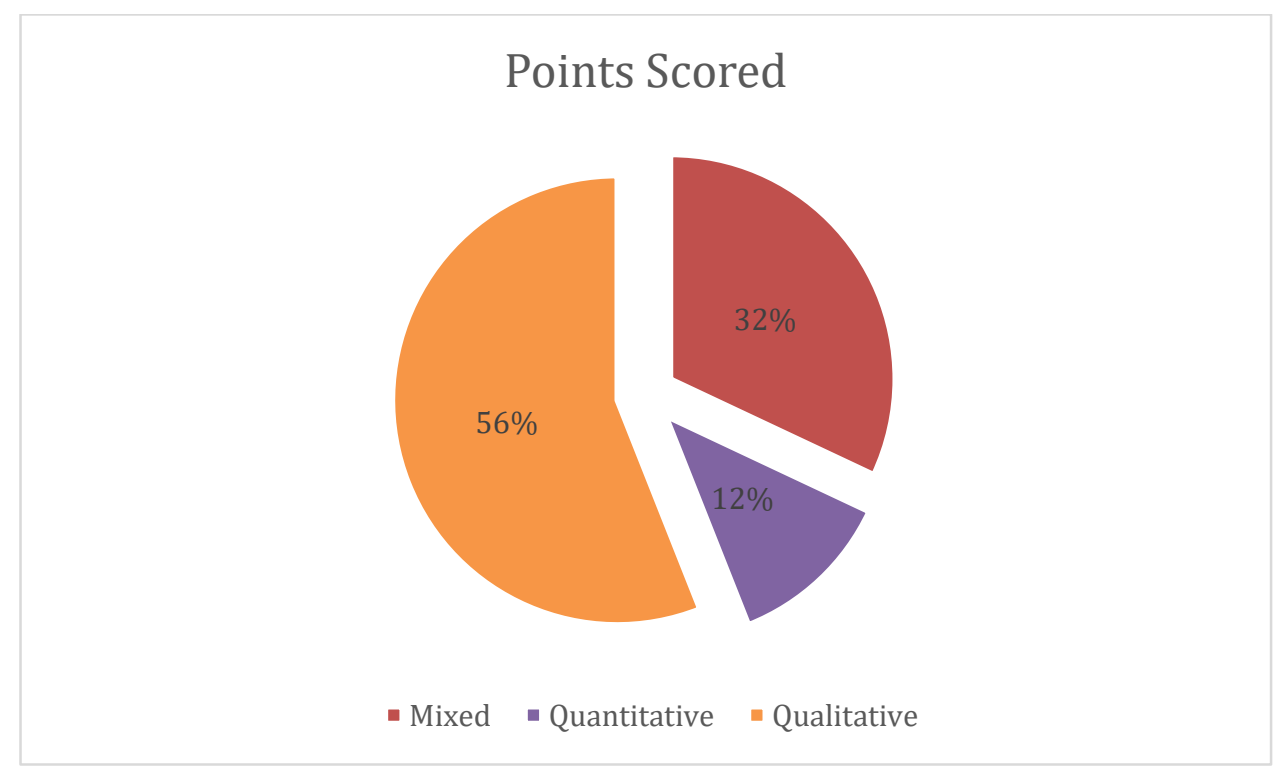

Source: Database of the research line. Master in Education UNIMINUTO.

Within these methodologies used, it is necessary to highlight the use of Case Studies or the interaction of investigations with mixed data against quantitative and qualitative instruments, with a predominance of observation in the latter case. There is evidence of highly rigorous processes in the previous validations of the instruments, mostly designed by students, and with support for authorizations and dissemination of the results in educational centers as ethical commitments of the research model.

Finally, the impacts generated in the communities and educational centers within the investigations must be identified to demonstrate the applicability and bets generated in the 
spaces. Taking into account that these are studies applied in context, dissemination processes such as those mentioned above were developed in order to generate knowledge of them by the academic community to achieve an active role in their development.

Below is a description of the impacts generated in the different contexts of Secondary and Higher Education:

Table 2: Impacts generated from investigations

\begin{tabular}{|l|}
\hline \multicolumn{1}{|c|}{ Impacts } \\
\hline Implementation of training programs. \\
\hline Transversal and collaborative projects with ICT support. \\
\hline Reflection on the teaching role according to ICT. \\
\hline Relationship of significant use and learning between ICT and foreign languages. \\
\hline Use of platforms in schools. \\
\hline Recognition and ownership of bullying concepts for prevention. \\
\hline Improving learning in the basic sciences with the introduction of ICT. \\
\hline Autonomous learning through video games. \\
\hline Teacher development through the acquisition of ICT skills. \\
\hline Use of ICT for the human development of students and the academic community. \\
\hline Sensitization of directives and families in the implementation of ICTs within the Curriculum. \\
\hline
\end{tabular}

Source: Database of the research line. Master in Education UNIMINUTO.

As can be seen, different impacts have been gathered and those were generated through research and, above all, those promoted reflection on the use of ICT within schools. In some cases, implementation and disruption began in comparisson to other more traditional teaching methodologies, and in others, the different resources and tools they already possessed were strengthened.

It is also necessary to emphasize that these studies allowed and facilitated the communications of the different populations involved (teachers, students, managers and families) in the teaching-learning processes, for this reason, there were spaces of discussions and decision making when showing the results. There was also a reflection of the different teaching plants on the role of ICT in their professional development and how they can help or not in their teaching work.

However, these reflections and discussions also occurred among the students. Studies that focused on attitudinal aspects and comprehensive training, emphasized phenomena such as 


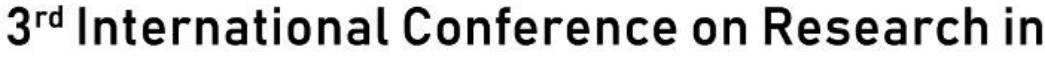 EDUCATION, TEACHING and LEARNING}

ROME, ITALY

bullying and how this was also exercised from the virtual and digital world, raising public awareness of this phenomenon.

Another impact focuses on aspects of training that were opened through research, both for teachers and students, which allowed the management of methods, resources and tools in their teaching-learning processes. It is important to highlight it as it becomes an added value within these research processes and is a part of the good lessons that are developed.

Articulation processes were also generated through projects with different areas of knowledge within the same institution and which were structured through the use of ICT, creating new strategies that will surely increase the motivation and meaningful learning of students.

As it is evident, the impacts were multiple in different spheres and always with the ultimate goal of improving the educational quality of future thinking contexts.

\section{Discussion \& Conclusions}

Below are the main conclusions of the applied research carried out by students enrolled in the line: use of ICT in learning environments.

The recognition of positive aspects in the characteristics of the learning style by students allows them to be more productive in the collaborative learning processes, thus generating greater influence on their peers, improving and enhancing individual and group performance, becoming a significant strategy for virtual learning environments, also benefiting the use of technological tools and strengthening collaborative learning in students during their subsequent studies.

Motivation and interaction are factors that are considered relevant in the process of teaching and learning in distance education, where the tutor must emphasize the tasks of orientation, support and guidance to the student aimed at achieving the planned competence objectives. It can be verified that orientation, guidance and above all motivation are key in these e-learning environments since the relationship between tutor and students is mostly asynchronous. Accordingly, we agree with Rosas (2017) when he states that the incursion of technology in schooled contexts not only implies a change at the software or hardware level but, rather, it must be accompanied by deep changes in teaching methods, contents, ways of evaluating them and the teacher's proper accompaniment.

Students are able to differentiate the use of ICT for learning and entertainment. An integration of these two aspects promotes fun or entertaining learning, so it is important to recognize that whether or not ICT tools are used, activities should be designed in such a way as to allow active participation in their learning; Therefore, it is worth remembering authors such as Rosas (2017) who states that the new pedagogical model that contemplates ICT refers to the "active participation of students instead of passive reception of information" (p.95). Teachers, for their contribution, value ICT tools, and make use of them because they are aware that technology is 


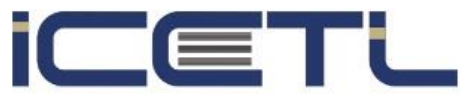

21-23 FEBRUARY, 2020

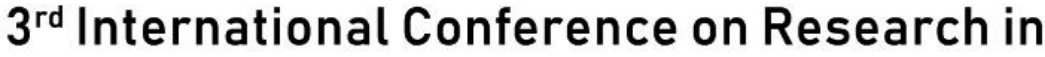 EDUCATION, TEACHING and LEARNING}

ROME, ITALY

the language that young people use. But there is also a conditioning to continue teaching without the use of ICT, which represents various opportunities to apply new knowledge to real-life situations, presentation of concepts and knowledge in multiple ways and not only through texts, learning as a collaborative activity rather than as an individual act, and an emphasis on processes of learning rather than memorizing information (Banco Mundial, 2003, p. 45).

With the above, we say that in virtual distance education, the problem in itself is not the distance to transmit the information or how to get the contents to the recipients (Keegan, 1996), rather, virtual distance education becomes an online environment that facilitates the construction of students' knowledge through the interaction of all participants (Tarasaw, 2017). Thus, distance consulting through virtual education not only allows access to information, but also enables students to put the learning into practice.

Distance education with virtual advice, requires solid ethical principles, it is not enough to extrapolate what is done in the classroom to a computer connected to the network, which makes it imperative to know for sure what the teacher must do for his teaching to be "real" besides significant; this is only possible with the promotion of autonomy and responsibility, the new model must seek transversality in order to achieve an education that forms the student in an integral way, not only as a subject of work but as a thinking and reflective ethical being, capable of changing things when necessary with honesty in order to achieve changse for the common good.

According to the results of the tests applied to the students of technology programs at UNIMINUTO, it was evidenced that these presented difficulties for reading and writing comprehension, therefore the PLEMA method (pre-reading, reading, preparation, memorization, self-evaluation) served to determine, the level of the different sequential areas in which the students and their competencies are located. It was concluded that the implementation of the PLEMA method is a learning option for improving reading comprehension in students at the university during the first semester of the technological careers at Corporación Universitaria Minuto de Dios Bogotá Sede Sur.

The information and communication technologies are reaffirmed as tools of high pedagogical value that make a great contribution to all areas of education. In the case of the website that supported the campaign to prevent school bullying, it was an excellent tool that helped the students observed to understand the components of this problem.

According to the pedagogical strategy developed by means of the video game Direnc, for the understanding of the color code of low power resistances, it is concluded that the application is feasible in the process of significant learning, since in the direct observations made in the training environment it was possible to evidence the apprehension of the knowledge in an easier way by the apprentice.

The implementation of the PLE (Personal Learning Environment) motivated creative productions, such as the case of the video, as well as moments of participation and reflection, which stimulates the development of many other skills and abilities in the learners. It was found that this strategy facilitates in addition to the learning of physical education, the development 


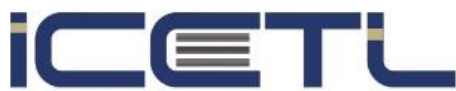

21-23 FEBRUARY, 2020

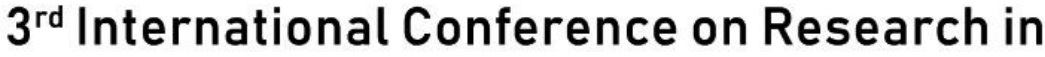 EDUCATION, TEACHING and LEARNING}

ROME, ITALY

of argumentative, propositive and interpretative capacities since what is now known as "digital generation" refers to the ease of use of new technologies by different persons; however, the lack of knowledge in the production of content through the use of technologies is evident; In other words, the new generations turn to technology to consume content, but not to generate it.

Attendance at a continuing education program for patient care in a critical state of health to the nursing staff that work in an intensive care unit generates a positive impact on health indicators, analyzed before the start of the diploma and after it, since these programs guarantee better patient care, as it allows a direct relationship between attendance at continuing education programs and the improvement of nursing practice; in addition, it allows staff to feel more integrated with The health team, because it has all the theoretical bases to contribute their knowledge and impact on care.

After analyzing each work and understanding its scope, it is proposed that each investigation evolves and continues to develop the analyzed themes as part of a permanent exercise of studying how technology is applied, used and appropriated in the teaching and learning process and how its actors, principally teachers and students, intervene with the objective of making technology an ally for the improvement of quality in education, which, according to Rivera (2016) implies teamwork between teachers, institutions and students in order to use technology to create quality content in addition to becoming responsible users of technological tools. This is why the promotion of this new educational paradigm requires more research projects or cooperative work in the classroom as methodologies of the teaching-learning process, since these are challenges that are closer to those that students will have to face throughout their personal and professional lives.

\section{Acknowledgment}

This article has been made possible by data from the research work done by the Master of Education students enrolled in the Project on the Use of ICTs in Learning Environments, for which the authors thank each of them for their valuable contributions.

\section{References}

[1] Awla, Hawkar. (2014). Learning Styles and Their Relation to Teaching Styles. International Journal of Language and Linguistics. 2. 241. 10.11648/j.ij11.20140203.23.

[2] Banco Mundial. (2003). Construir Sociedades de Conocimiento: Nuevos Desafíos para la Educación

Terciaria.

Recuperado

de http://siteresources.worldbank.org/Tertiaryeducation/Resources/Documents/ ConstructingKnowledge-Societies/CKS-spanish.pdf 


\section{$3^{\text {rd }}$ International Conference on Research in EDUCATION, TEACHING and LEARNING}

[3] Byrne, B.M. (2001). Structural Equation Modeling with AMOS: Basic Concepts, Applications and Programming. London: Lawrence Erlbaum Associates, Inc

[4] Casablancas, S. (2017). No es malo perder el rumbo: reconfiguraciones del rol docente en el contexto digital en Sevilla H., Tarasow F., y Luna, M. (coords.) (2017). Educar en la era digital. Guadalajara: Pandora.

[5] Cobo, C. (2019): Acepto las Condiciones: usos y abusos de las tecnologías digitales. Fundación Santillana, Madrid.

[6] Fong, C., Flores, K. y Cardoza, L. (2017). La teoría de recursos y capacidades: un análisis bibliométrico. Nova scientia [online]. 2017, vol.9, n.19, pp.411-440. ISSN 2007-0705. Available: http://dx.doi.org/10.21640/ns.v9i19.739.

[7] Fundación Telefónica. (2018). 50 estrategias para 2050. El trabajo y la revolución digital en España. Available: https://www.fundaciontelefonica.com/culturadigital/publicaciones/50-estrategias-para-2050/636/

[8] Keegan, D. (1996). Foundations of Distance Education (pp. 33-89).Estados Unidos / Canada: Routledge Studies.

[9] Redecker, C. (2017). European Framework for the Digital Competence of Educators: DigCompEdu. Punie, Y. (ed). EUR 28775 EN. Publications Office of the European Union, Luxembourg, ISBN 978-92-79-73494-6, doi:10.2760/159770, JRC107466Chen, W. K. (1993). Linear Networks and Systems, Belmont, CA: Wadsworth, pp. 123-135.

[10] Rosas, Ch. Patricia (2017). Tecnologías para el aprendizaje y desafíos curriculares en el contexto digital en Sevilla H., Tarasow F., y Luna, M. (coords.) (2017). Educar en la era digital. Guadalajara: Pandora.

[11] Sevilla H., Tarasow F., y Luna, M. (coords.) (2017). Educar en la era digital. Guadalajara: Pandora.

[12] Tarasaw, Fabio (2017). Educación en línea, el diseño en línea como hackeo en el contexto digital en Sevilla H., Tarasow F., y Luna, M. (coords.) (2017). Educar en la era digital. Guadalajara: Pandora (p.121-134) 